\title{
Early and dynamic socio-academic variables related to dropout intention: a predictive model made during pandemic
}

\author{
Jorge Maluenda-Albornoz ${ }^{1 *}$, Valeria Infante-Villagrán², Celia Galve-González ${ }^{3}$, Gabriela Florez-Oyarzo ${ }^{4}$, José Be- \\ rríos-Riquelme ${ }^{5}$

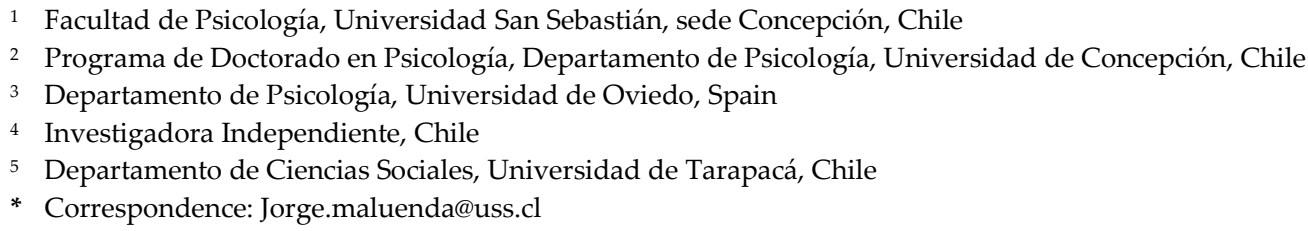

\begin{abstract}
Social and academic integration variables have shown to be relevant for the understanding of university dropout. However, there is less evidence regarding the influence of these variables on dropout intention, as well as predictive models that explain their relationships. Improvements in this topic become relevant considering that dropout intention stands as a useful measure to anticipate and intervene on this phenomenon. The objective of the present study was to evaluate a predictive model for the university dropout intention that considers the relationships between social and academic variables, during the first university semester of 2020. The research was carried out using a cross-sectional associative-predictive design, with a convenience sampling $(n=711)$ due the restrictions of pandemic period. The results showed a good fit of the proposed hypothetical model that explains $38.7 \%$ of dropout intention. Both social support and perceived social isolation predicted the sense of belonging, and through it, engagement. Previous academic performance predicted early academic performance, and through it, engagement. The set of variables predicted the intention to quit, through engagement. These results are a contribution both to the understanding of the phenomenon and to guide potential interventions in the early stages of the university experience.
\end{abstract}

Keywords: dropout intention; perceived social isolation; perceived social support; engagement; sense of belonging; higher education

\section{Introduction}

\subsection{University dropout and dropout intention}

University dropout in Latin America and the Caribbean is a critical problem with rates that can reach $54 \%$, and an approximate $22 \%$ of the population between 25 and 29 years old has abandoned their studies [1]. In this context, the first year of university is the greatest concern because it produces a higher dropout rate in higher education, making the educational process difficult at an early stage [2]. Chile is no exception, reaching dropout rates of $26.4 \%$ at the higher education level and $23.1 \%$ at the university level during the first year of studies [3]. The effects that this entails an impact at the individual and family level, with repercussions on the life project and the family economy [4-5] at the institutional level, impacting on quality and efficiency indicators and at the social level, affecting social and economic development due to the decline in human capital [6].

In recent years, there has been an important interest in studying the dropout intention of university studies because it is a variable that can be measured early to anticipate complete dropout. Its measurement in early stages, for example, during the first year, would influence the decision of the students through strategies to support them to a better social and academic integration in university. In addition, some research shows the 
importance of studying the perceptions of university students about their dropout intention [7].

It has been observed that the variables that influence the social and academic integration of students are linked to dropout [8-11], and may also influence dropout intention [12-15]. However, the research is still incipient, and it there is room for improvement in the refinement of the differential importance of these variables, as well as the elaboration of a theoretically coherent model that allows the prediction of their occurrence.

It is important to indicate that the COVID-19 pandemic has brought a series of important consequences for the development of university education, giving rise to a remote or hybrid educational process, without the teachers and university systems having been sufficiently prepared to face this rearrangement [16-18]. This has implied an accelerated adjustment of teachers in the necessary tools for remote education, a change in teaching strategies and the updating of technological supports [19-20].

Mooney and Becker [21], carried out a study where they propose that the events around COVID19 are a challenge for the sense of belonging of many students, mainly for those entering the first year. In it, $50 \%$ of the students who participated reported that the levels of stress and anxiety related to COVID were extremely challenging or very challenging. This study shows that COVID-19 affects to a greater extent the sense of belonging in men and women who do not feel they belong, being statistically significant in men, and this would be explained because virtual environments would not be able to replicate the key facets of presence [22]. An additional explanation is that the sense of belonging, and the physical space of the campus would be closely related [23], and that belonging would increase with social interaction [24].

The characteristics of remote education in times of pandemic could introduce differences in the influence that predictive variables have on dropout intention in the context of a regular study. For example, students have had to adjust to the new educational conditions with difficulties related to access and technological literacy, the adjustment of the home to offer space, study and work conditions in very diverse socioeconomic backgrounds (o contexts) among families [25].

In addition to all the above, today the educational process takes place in a context different from the usual, marked by the lack of direct interpersonal contact, less possibility of teacher control of the student's activity and, therefore, the need for skills in the students to be able to face their learning more autonomously.

\subsection{Support and Perceived social isolation}

There are different sources of support that can be provided by the community, by social networks and trusted people. However, it tends to come more frequently from people with whom you trust and share a greater degree of intimacy [26].

Research has shown that peer and teacher support influence the decision to drop out of university $[15,27]$. This relationship is because the most immediate support that students have during their studies is that of their significant teachers and their peers.

Perceived social support is defined as the evaluation made by the student regarding the quantity and quality of social support available, if its use is necessary [28]. In this way, it constitutes a subjective perception of the availability of the social network and the satisfaction of personal needs through support [29].

Supports can fulfill both an expressive function with an end in itself (e.g. sharing a problem or a moment of pleasure) and an instrumental function aimed at achieving a specific objective or good (e.g. receiving education or information) [30]. This distinction is relevant if we consider results observed in university dropouts, where social interaction specifically was linked to support in academic work shows a more important effect [31].

In the current educational context, social variables can play a very important role due to the confinement and forced social isolation in which university studies are. It is possible that isolation has effects in different dimensions such as socio-emotional balance, which will be increased in students with pre-existing problems [32]. 
Perceived social isolation is defined as the subjective evaluation regarding the availability of contacts or social ties [33] to the extent necessary for each person.

The attributional discrepancy theory is important at this point, both for understanding perceived social support and social isolation. The subjective evaluation that the students make of their social relationships varies according to their own standards [34]. In this way, the perception of support and social isolation considers the level of social contact that people require and that can be very heterogeneous for each one. In other words, students may perceive more or less support, isolation or social belonging with respect to the available objective levels $[28,33]$.

Both support and social isolation have shown their importance in university studies due to their impact on social integration of students and the consequences of this on mental health and the networks available to advance in academic activities [35-36], in addition to being directly related to lower dropout rates [37]. Therefore, the greater the social integration, the lower the probability of drop out, where social integration is being affected by both social support and social isolation.

College students who do not make effective connections with their peers and professors are likely to feel alienated and/or marginalized. When this situation is sustained over time, it can become an incentive for dropout [35]. In addition, it has been observed that social isolation can severely deteriorate the educational experience, being linked to anxiety, depression, and stress [35] and disengagement with studies [38]. But having social support can act as a buffer for student stress and discomfort in difficult situations, favoring conditions that allow a better approach and decision-making [39], which can act as a protective factor against dropout intention.

It has been observed that the perceived social support and the interpersonal relationships that students establish with their peers, teachers and members of the university campus are fundamental aspects to develop a sense of belonging [40-44], an aspect inversely related to the dropout intention. This is because social support and positive interactions are essential for the development of a sense of belonging in university students $[40,45]$. The support of peers and parents has also shown to influence the sense of belonging to the institution and has been linked to a greater institutional engagement [46].

Student's social integration with peers and teachers has shown to be a direct and strong predictor of academic engagement and an indirect predictor of the intention to stay or dropout [47]. The perception of support from teachers has been negatively related to the dropout intention [48]. So, the greater the social integration, the greater the academic engagement and the less dropout intention.

A few studies have directly measured social isolation in college students during the pandemic [49]. Regarding this specific scenario it has been observed that social isolation influences the mental health of students [50-57].

Some studies during the current pandemic have observed similar results to those in the regular educational context: social isolation in university students is related to mental health effects such as stress, worries and insomnia $[58,59]$.

Social integration variables have been one of the most studied in recent years, among which, recently, social adaptation and the sense of belonging have become relevant $[27,60]$.

\subsection{Sence of belonging}

The sense of belonging is defined as the perception of membership or feeling part of the educational organization (study program) in which they study [61]. Feeling belonging to the career implies that the student feels valuable and respected in their own educational program [40,43-45,62-66]. It implies a perceived bond between the student and others, which unites them to a group or community, even in difficult moments or in the face of challenges [67], and the impulse that mobilizes them to create and maintain meaningful and lasting interpersonal relationships [68]. 
The model proposed in this study focuses on the sense of belonging to the study program in which the students study. So, the kind of sense of belonging that is referred to in this study is the sense of career belonging.

The sense of belonging arises because of the process of integration of a person in their organization and, consequently, because of the levels of support or isolation perceived by the students. When students connect with the formal academic, social, and cultural learning environment of the academic community, they develop a sense of belonging that translates into a desire to stay and complete their educational goals [69].

Belonging students share cultural aspects of the organization and voluntarily participate in the life and activities of the organization [70]. When there is a deep sense of belonging, the student's self-definition can be connected to what defines the organization, affecting their identity and behavior [71].

The social integration of students fosters a sense of belonging to the community, a variable that has shown to be a predictor of permanence in university studies in a regular educational context [46]. Therefore, when the student is socially integrated, it favors the development of a sense of belonging.

On the other hand, when students do not feel valued and respected by others, or do not feel that they belong to a social environment, they are more likely to drop out their studies [72], being the sense of belonging to the career a significant predictor of the dropout intention in university students [73].

The link between the sense of belonging and the dropout intention is due in part to the fact that it strengthens the engagement of students. It has been observed that the similarity and connection that students perceive with respect to their immediate academic community has been a predictor of engagement [74]. It has also been shown to be a predictor of the exertion of committed behaviors such as respecting the rules or assuming more functions than the mandatory ones [75].

The pandemic of COVID-19, poses various challenges for university students, including adjusting to an online educational system while keeping their academic and work duties and responsibilities up to date, adjusting to changes in terms and schedules, and the lack of a space or physical context for interaction where they can share their concerns and experiences with peers [76]. In a study carried out by Markel and Guo [22] during the first months of the COVID-19 pandemic, they showed that, in virtual learning environments, although remote technologies can contribute to inclusion, they also pose additional barriers for students.

It has been observed that high levels in the sense of belonging in university students contributes to increasing their levels of participation, being able to seek help in the face of difficulties, feeling less alone, anxious or depressed, increasing the use of self-regulation strategies and raises levels of academic self-confidence and motivation [64,66,77]. In addition, various investigations have observed that the sense of belonging turns out to be a direct predictor of study engagement, dropout, and permanence in studies $[40,41,45,65,66,73,77-80]$.

\subsection{Academic variables and university dropout intention}

The relationship between academic performance and dropout has been reported many times showing, in general, that performance is a significant predictor of college dropout $[2,9]$.

Academic performance is understood as the level of knowledge demonstrated in an area or subject compared to the age norm and academic level [81]. However, in practical terms, performance is usually measured from classroom assessments that do not necessarily entail associated standardizations. Performance is commonly considered as the level of achievement that a student obtains in their training process, expressed through a numerical assessment [82]. Their relationship has been investigated and described as an academic precedent for dropping out of studies where the score in the University Selection Test (PSU) has been the most used in the Chilean context [83,84]. 
The theoretical relationship rose between previous performance and dropout lies in the fact that previous performance reflects the academic abilities that students develop before entering higher education, which influence the academic integration process [85]. In this way, the level of prior academic preparation of students would influence the mastery of basic knowledge and skills necessary for current studies.

The relationship between academic performance during studies and dropout has been less explored and could be important in the student's decision-making regarding whether to remain or abandon ongoing studies.

For Bernardo et al. [86] academic performance during studies operates as an indicator for the student about their degree of academic integration, which becomes a key element in the decision to remain or abandon studies. In addition, there is research that has shown its influence on student decision-making about permanence and the effect it has on university dropout [87].

Early academic performance would operate as feedback on the effectiveness of the efforts made to study and the ability to face a university career. In addition, it becomes vital information to decide in terms of cost-benefit on the continuation of the studies [88].

\subsection{Engagement and dropout intention}

Different studies with university students have shown that the level of engagement exhibited by students proves to be a strong significant predictor of dropout in university students $[13,73,89]$.

Engagement is understood as the set of manifestations of motivation with studies [90] which have developed, over the last decades, theories that group this phenomenon into three main dimensions [91]: the behavioral dimension, which would refer to all those behaviors carried out by the student who is interested in learning; the cognitive dimension, which would refer to all those thoughts, beliefs and perceptions about the importance of academic work and the effort that it entails; and the emotional dimension, which includes the feelings and attitudes that the student experiences around the institution.

In this sense, the engagement proposal is based on the Theory of Self-determination (TAD) [92]. This is understood as the set of manifestations of motivation for studies [90] that arises from the satisfaction of the needs of competence, autonomy, and relationship in the context of studies [90]. In the educational context, the need for autonomy is satisfied when the student feels that he or she makes choices and is motivated by intrinsic rather than external factors. The need for competence is favored when the structure of the class allows the desired results to be achieved. The need for relationship is satisfied when the student establishes relationships with their teachers and peers based on support and concern [90].

As for the relationship between engagement and dropout intention there is a much smaller volume of research. Despite this, it has been observed that engagement is also a strong significant predictor of dropout intention [93,94].

During 2020 and 2021, most of the published studies have shown that the current educational context has generated damage in the motivation and participation of students [20,95] and a decrease in their levels of engagement [96,97]. Some studies have attributed this deficit to factors associated with mental health such as stress, worries and insomnia during confinement, which affect the energy and vigor levels associated with student engagement associated with the situation of social isolation and remote education $[58,59]$.

A predictive associative study during the pandemic with university students from nine countries found that engagement was a positive predictor of performance and a negative predictor of dropout intention [98]. Another study carried out during the pandemic with Chilean university students observed that the expectations about their level of engagement and about their performance during the semester were shown to be predictors of their early dropout intention [19]. 
All the variables previously described, considered dynamic variables since they are potentially modifiable predictor variables, constitute a set of key factors to understand the phenomenon of university dropout, as the evidence presented preliminarily has shown. The variables included in this research represent two specific virtues: a) are variables that can be influenced during university studies favoring potential interventions; b) are variables that can be measured in very early stages of the educational process, and therefore, favor a rapid response by universities in the face of risk situations.

The main objective of the present research was to evaluate a predictive model for the university dropout intention that considers the relationships between previous and early academic performance, sense of belonging to the career, support and perceived social isolation in the career, and academic engagement during the first university semester of 2020. This study, therefore, has been developed during the start of the COVID-19 pandemic in Chile. The hypothetical model of relationships based on the theoretical and empirical aspects previously raised is observed in Figure 1.

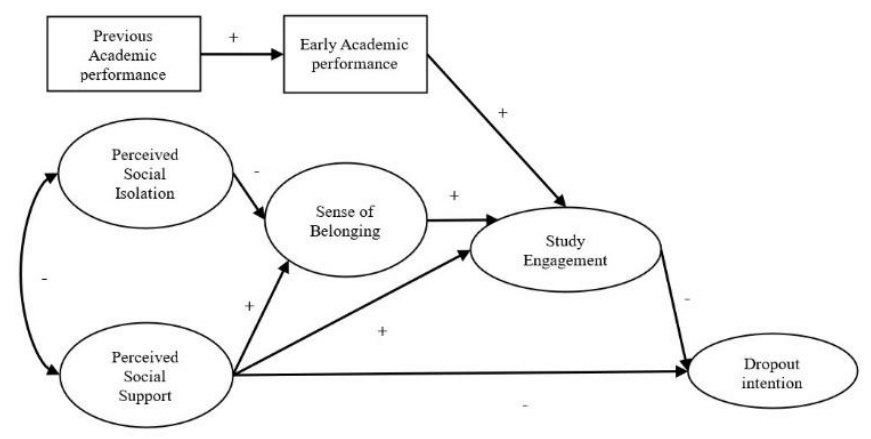

Figure 1. Hypothetical model for Dropout Intention.

\section{Materials and Methods}

\subsection{Participants}

The sample was made up of 711 first-semester students enrolled in 2020 from a Chilean university, equivalent to $16.78 \%$ of the total population. It was distributed among 285 men (40.09\%), 422 women (59.35\%) and 4 students who identified with another preference $(0.56 \%)$. The average age of the students was 18.8 years, with a standard deviation of 1.7 years, a minimum of 17 years and a maximum of 33 .

The students were recruited through the authorities of their respective careers; their participation was voluntary and did not imply compensation of any kind.

The distribution of students according to the disciplinary area of their career and the dropout percentage reported by the degree in which the student enrolled during 2020 is shown in Table 1.

Table 1. Distribution of participants by career area and dropout rate.

\begin{tabular}{ccccc}
\hline Career area & High dropout rate & $\begin{array}{c}\text { Medium drop- } \\
\text { out rate }\end{array}$ & $\begin{array}{c}\text { Low dropout } \\
\text { rate }\end{array}$ & Total \\
\hline Legal, economic and administrative & $\mathrm{N}=20$ & $\mathrm{~N}=28$ & $\mathrm{~N}=5$ & $\mathrm{~N}=53$ \\
Agriculture and forestry technology & $\mathrm{N}=21$ & $\mathrm{~N}=17$ & $\mathrm{~N}=48$ & $\mathrm{~N}=86$ \\
and sciences & $\mathrm{N}=64$ & $\mathrm{~N}=57$ & $\mathrm{~N}=46$ & $\mathrm{~N}=167$ \\
Social sciences and humanities & $\mathrm{N}=70$ & $\mathrm{~N}=11$ & $\mathrm{~N}=39$ & $\mathrm{~N}=120$ \\
$\quad$ Exact and natural sciences & $\mathrm{N}=22$ & $\mathrm{~N}=42$ & $\mathrm{~N}=91$ & $\mathrm{~N}=155$ \\
Technology and health sciences & $\mathrm{N}=48$ & $\mathrm{~N}=72$ & $\mathrm{~N}=10$ & $\mathrm{~N}=130$ \\
Engineering science and technology & $\mathrm{N}=245$ & $\mathrm{~N}=227$ & $\mathrm{~N}=239$ & \\
\hline Total & &
\end{tabular}




\subsection{Design}

The current research was carried out using a cross-sectional associative-predictive design. The selection of the participants was carried out using a non-probability convenience sampling due to the restrictions imposed by the COVID-19 pandemic for access to the participants. All first-semester students enrolled in 2020, belonging to a Chilean university, were invited to participate openly and voluntarily. The voluntary invitation was made by email. The students read and accepted an informed consent approved by the university's research ethics committee, which led them to the instrument in electronic format. The data collection was carried out during May and June of the year 2020 to have students who have had initial experience at the university and have their first qualifications.

\subsection{Instruments}

An electronic questionnaire was made from different instruments that have been adapted to the Chilean context with recent evidence of validity and reliability for the variables of this research. In those studies all the psychometric properties were tested using Confirmatory Factor Analysis (CFA), the Cronbach's alpha index and the McDonald's omega index.

The instrument consisted of 33 items whose response format was through a Likert-type scale of 1 to 7 points. It included:

- University Student Engagement Scale (15 items) created by Maroco et al. [89] and adapted to Chilean university students [13]. This instrument measures engagement as the result of high motivation for studies in the career context. The validation study showed a bifactorial structure with one general factor and three subfactors: Interest (5 items), Effort (5 items) and Participation (5 items). In the adapted version the fit indices showed good performance of the bifactorial model $\left(\chi^{2}=210.276, p<.001\right.$; RMSEA $=.047$ (95\% IC: .040-.055; CFI=967; TLI=954) as well as reliability $(\alpha=.841 ; \omega=.843)$ and criterion validity.

- Membership factor of the Organizational Identification Questionnaire with Study Centers created by Yañez et al. [99] and adapted to Chilean university students [100]. It measures through 4 items the degree of belonging perceived of the students within the career they are studying. The adapted version showed good fit indices for a one factor structure $\left(\chi^{2}=3.126, \mathrm{p}=.20\right.$; RMSEA=.028 (95\% IC: .000-.085; CFI=999; TLI=999; RSMR=.005) as well as reliability $(\alpha=.815 ; \omega=.834)$.

- Perceived social support items inspired by the measurement carried out in Chilean university students in the FONDECYT project $\mathrm{N}^{\circ} 1161502$, adapted to refer specifically to the career level [101]. These 4 items measure the perception of having a reliable network in the university context (by peers and professors) when it is needed. It showed good fit indices for a one factor structure $\left(\chi^{2}=11.616, p=.003\right.$; RMSEA $=.072$ (95\% IC: .041-.131; $\mathrm{CFI}=997 ; \mathrm{TLI}=992 ; \mathrm{RSMR}=.011)$ as well as reliability $(\alpha=.798 \omega=.823)$.

- Perceived social isolation items based on the UCLA Loneliness Scale - revised version [102] adapted to refer specifically to the career level. It measures through 4 items the perception of lack of social relationships and meaningful ties in the university context (with peers and professors). It showed good fit indices for a one factor structure $\left(\chi^{2}=5.741, \mathrm{p}=.056\right.$; RMSEA=.051 (95\% IC: .000-.103; CFI=999; TLI=997; RSMR=.008) as well as reliability $(\alpha=.800 \omega=.817)$.

- The dropout intentions were measured from 4 items taken from FONDECYT project $\mathrm{N}^{\circ} 1161502$ that have been previously used in the same population and that refer to the student's dropout intention of university [101]. It showed good fit indices for a one factor structure $\left(\chi^{2}=9.732, p=.007\right.$; RMSEA $=.074$ (95\% IC: $.032-.123$; CFI=999; TLI=996; RSMR $=.004)$ as well as reliability $(\alpha=.834 \omega=.834)$.

- One item was considered to collect the prior academic performance, which is measured through the simple average of grades obtained by the students in the national university selection test called "Prueba de Selección Universitaria" (PSU). 
- Finally, one item was considered to collect early academic performance. It corresponds to the simple average of grades obtained by the student in the middle of the first academic semester (May-June 2020).

\subsection{Analysis}

The evaluation of the proposed model and the associated research hypotheses followed the 3 phases proposed by Kline [103] for the evaluation of structural models:

- Specification of the evaluated model. The included variables and its relationships were specified based on the literature review. The result was the hypothetical model presented in figure 1 which consisted of 5 latent and 2 observed variables as principal components of this research.

- Estimation by "Weighted Least Square Mean and Variance" (WLSMV). It allows work with continuous and categorical variables at the same time [104]. In addition, it is an estimator that works well with samples of moderate size and complex models [105].

- Evaluation of the model. Goodness of fit was calculated to evaluate the hypothetical model. Based on these results and theoretical background decisions about re-specified model were made. The reference values used to evaluate goodness of fit were: significant $\chi^{2}$, Decrease in the NCP value in the re-specified model, CFI and TLI $\geq$ .90, RMSEA $\leq .08$ [106], $\omega>.70, \alpha>.70$ [106,107]. - All analyzes were performed using the statistical software MPLUS version 8 .

\section{Results}

\subsection{Preliminary analyses}

Table 2 shows the means, standard deviations, skewness, kurtosis, minimum and maximum value. All asymmetry and kurtosis values were less than 3 , which show that the structure of the data tends to approximate a univariate normal distribution except for the dropout intention, which presents a kurtosis value slightly higher than this criterion. The results of the Kolmogorov-Smirnov normality test did not show statistically significant differences in any of the variables evaluated. This result corroborates what was previously found in the descriptive analysis presented. Thus, the data is assumed to have a univariate normal distribution.

Table 2. Descriptive statistics.

\begin{tabular}{cccccccc}
\hline Variable & $\mathbf{n}$ & Min & Max & Mean & \multicolumn{2}{c}{ SD } & Skewness Kurtosis \\
\hline Previous academic performance & 711 & 200 & 809 & 623,56 & 71,12 &,- 42 & 2,25 \\
Early academic performance & 711 & 30 & 70 & 57,43 & 6,85 &,- 70 &, 26 \\
Sense of belonging & 711 & 4 & 28 & 19,99 & 5,04 &,- 60 &,- 19 \\
Perceived social support & 711 & 4 & 28 & 17,29 & 5,59 &,- 32 &,- 50 \\
Isolation & 711 & 4 & 28 & 11,73 & 5,39 &,- 54 &,- 46 \\
Study engagement & 711 & 18 & 105 & 82,48 & 11,93 &,- 94 & 1,99 \\
Dropout intentions & 711 & 4 & 28 & 7,19 & 4,40 & 1,77 & 3,30 \\
\hline
\end{tabular}

\subsection{Research results}

The evaluation of the proposed model showed an appropriate fit in all the fit indices tested except for the $\chi^{2}$ index, which turned out to be significant. However, it has been observed that this indicator tends to be misaligned with large sizes [105]. Its correction through the NCP ratio reaches a small value, an indicator of a good fit [106]. All these values are shown in Table 3 . It is important to add that the 2 criteria to obtain the minimum required/desirable sample size proposed by Hair et al. [106] were considered: the $10 \mathrm{x}$ rule and the minimum $\mathrm{r} 2$. According to the above, it was observed that the recommended, as well as the desirable, minimum sample size was 308. 
Table 3. Initial model Fit Indices.

\begin{tabular}{cccccccc}
\hline Model & $\chi^{2}$ & gl & NCP & CFI & TLI & RMSEA & SRMR \\
\hline Initial model & $\begin{array}{c}2102,512 ; \\
\mathrm{p}<.001\end{array}$ & 485 & 2.27 & .931 & .924 & $\begin{array}{c}.068 \text { IC 95\% } \\
{[.065-.072]}\end{array}$ & .071 \\
\hline
\end{tabular}

The standardized beta values of the model show significant values in most of the relationships proposed between the variables, except for the routes that include the direct influence of perceived social support on study engagement $(\beta=.024, p>.05)$ and on dropout intention $(\beta=-.030, \mathrm{p}>.05)$. For the other relationships, the observed standardized beta values were significant and fluctuated between moderate and strong values $(\beta=$ $.217 \beta=-.796, \mathrm{p}<.01)$. The initial model is shown in Figure 2.

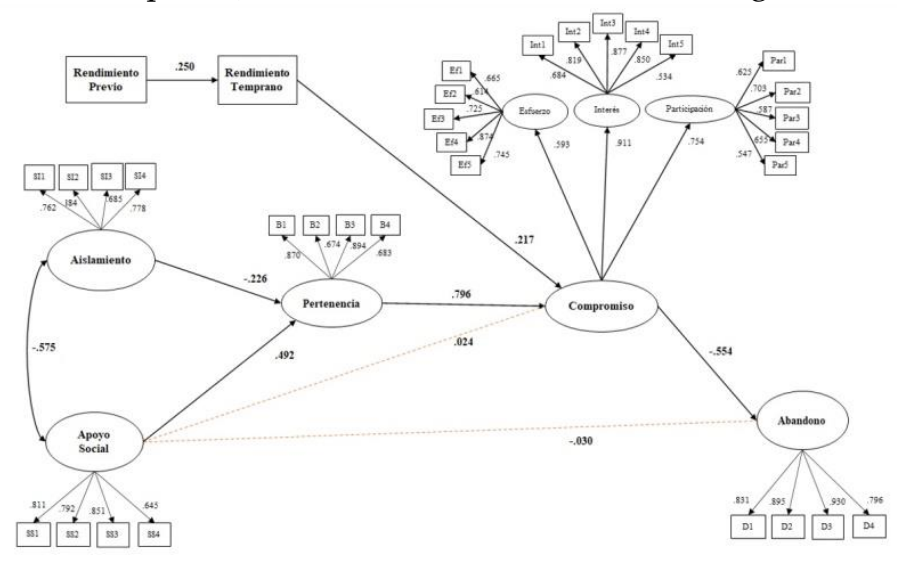

Figure 2. Tested model for Dropout Intention. $\mathrm{p}$ value were all $\mathrm{p}<.001$.

A re-specified model was evaluated without the relationships that showed not to be significant, considering as a hypothesis that the effect of social support on the dropout intention occurs through a double mediation given by the sense of belonging and academic engagement. The new model improved all the fit indices (Table 4) except for $\chi^{2}$, which turned out to be significant. However, the contrast in the NCP values showed a better fit in the second model. The re-specified model and its values are shown in Figure 3 and Table 4 respectively. In this sense, the new model showed a better fit in all the indicators and reflected $38.7 \%$ of the explanation for dropout intention.

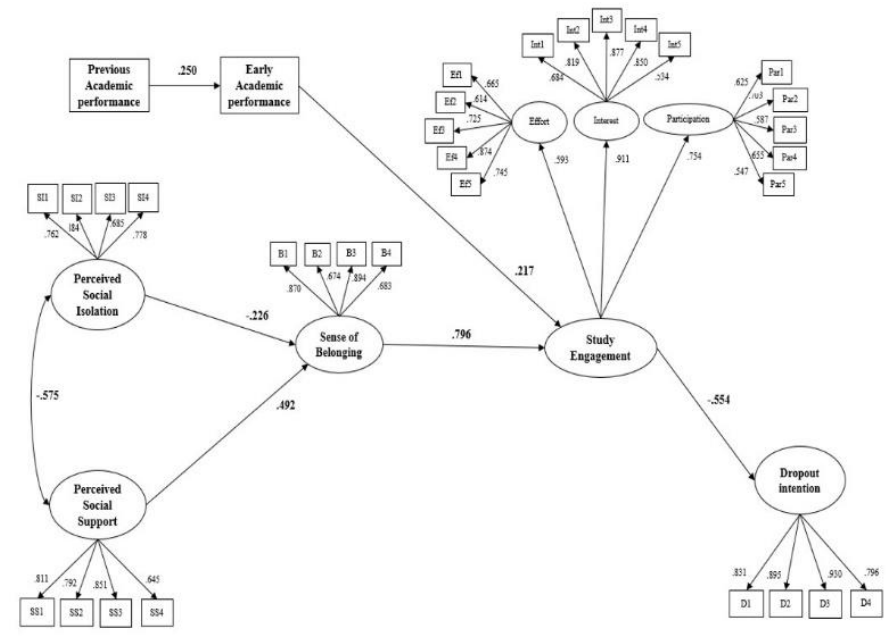

Figure 3. Re-specified model for Dropout Intention. $\mathrm{p}$ value were all $\mathrm{p}<.001$.

Table 4. Re-specified model Fit Indices.

\begin{tabular}{cccccccc}
\hline Model & $\boldsymbol{\chi}^{\mathbf{2}}$ & gl & NCP & CFI & TLI & RMSEA & SRMR \\
\hline Re-specified & 1995,$754 ;$ & 486 & 2.12 & .955 & .950 & .066 IC 95\% & .071 \\
\hline
\end{tabular}




\section{Discussion}

The present research proposed a model based on social and academic integration variables to explain university dropout intention in first-year students. The research is based on two essential assumptions that are at the base of the hypothetical model proposed. In first place, it was argued that the integration of a student in the social life of a career is related to the sense of belonging, variable with a strong influence on the degree of engagement that he or she manifests with their academic activities and with the human group that makes up the career, which influences the decision to stay or drop out of their current university. Second, it has been proposed that academic performance can act through the capacities developed to face academic life and as a source of information that affects decision-making regarding staying or leaving studies.

To these assumptions, three key specifications are added, which this research aims to provide evidence for. In the first place, the importance of specifying the measurement of variables at the career level because it is the immediate context in which students operate and the one that may have the greatest impact on their decisions during the educational process. The only exception to this condition was previous performance due to its past nature. Second, the importance of considering variables that can be measured early in the educational process was raised. This is due to the need to have relevant information for the decision to drop out or remain in the studies that is possible to know quickly and that allows decisions to be made before the abandonment is consumed. Third, the need to work mainly with predictive variables that were potentially modifiable (dynamic variables) was proposed to contribute to the knowledge that can be applied in the improvement of institutional processes.

From these results it is possible to indicate the fulfillment of the objective of this study. The results showed an adequate general model fit, with most of the hypothetical relationships raised being significant with moderate to strong values. However, the routes that include the direct influence of perceived social support on study engagement and on dropout intention were not statistically significant, reason why it was decided to re-specify the model. The new model showed a better fit in all the indicators and reflected $38.7 \%$ of the explanation for dropout intention.

From the re-specified model, it is possible to conclude that both the social [48] and academic variables considered have a relevant influence on the dropout intention, reaffirming what has already been described in the preliminary research $[73,98]$.

In the present model, the influence of the social and academic integration variables predicts engagement, which acts as the main mediating variable of the model. The influence of social support and perceived social isolation, in turn, is mediated by the sense of belonging to the career, a variable that exerts a strong influence on engagement. The influence of previous academic performance on engagement is in turn predicted by early academic performance.

The original model was proposed with an independent influence between social and academic variables due to its measurement in the same time cut-off. It is not reasonable to argue that current perceived social support, isolation and sense of belonging influenced early performance that had already been achieved.

\subsection{Academic variables and dropout intention}

The results reaffirm what has already been observed in previous research. On the one hand, previous academic performance is a predictor of early academic performance [108]. However, the form of influence of previous academic performance on early one is something that should be deepened in later research, since it is possible that it is indica- 
tive of the influence of previous learning and/or the previously developed sense of self-efficacy on current learning.

On the other hand, early academic performance is a predictor of engagement as observed in previous research $[109,110]$. At this point, it is possible that early academic performance acts as an informative factor [86] that fuels student motivation for studies.

Neither of the two variables was shown to be a direct predictor of the dropout intention, according to the original approach, with engagement being an important mediator of its influence on the dropout intention. Thus, both types of performance only affect the dropout intention by affecting this cognitive-motivational variable. However, it seems important to understand that engagement is understood as the set of manifestations of motivation by studies [90] that include behavioral, cognitive and emotional dimensions [91]. This means that taking these dimensions into account is essential to understand the correlation between academic variables and the intention to remain in higher education.

It is also important to note that academic performance may not have shown to be a predictor of dropout intention due to the time the data was collected, since student grades tend to change as they adapt to the new educational context, not ruling out that this may influence later.

However, it is also important to understand that the current contingency due to the COVID-19 pandemic has been able to influence the results of the research, considering that early academic performance of students may have been modified considering the online modality. In addition, this may have influenced the engagement of students to a degree. Therefore, the interpretation of the results obtained must take into account the current contingency in order to be able to replicate the data in detail in the future and in different contexts.

\subsection{Social variables and the dropout intention}

The observed results suggest that the perceived social integration, given by the perception of support and lack of isolation, affects the sense of belonging they perceive to the human group that makes up their career. The sense of belonging, in turn, affects the engagement experienced by students, mobilizing specific motivational components such as interest, participation and effort linked to studies. In turn, experienced engagement is strongly linked to early dropout intention. This chain of relationships shows the relevance of social variables on the motivation of students and, through it, on their decisions associated with the continuity of their studies, especially if the emotional dimension is considered, as previously stated.

It is important to indicate that the measures carried out contemplate perceptions about social integration, which highlights the importance of its evaluation in the measure of individual needs, according to the approaches of the theory of attributional discrepancy [34].

On the other hand, it is relevant to remember that, in this study, social variables have been measured considering focus on relationships with peers and teachers, showing the relationship between these and dropout intention, according to what was found in previous research with Chilean students $[13,19,29]$. The results suggest the importance of these relationships in the context of the career, highlighting their important influence on dropout intention. This could help clarify the types of support and isolation relevant to dropout intention.

Social support did not show to be a direct predictor of engagement as suggested in the initial model. As mentioned, the results show that the influence of social variables is explained by the presence of a sense of belonging. In this way, it is possible to observe that the social support of peers and teachers can affect the engagement of students by affecting how much they feel they belong to their career. At this point the theory of attributional discrepancy becomes relevant again since, how much support and how much belonging the students perceive and need is an idiosyncratic aspect of their experience. 
This finding is an important contribution given that most of the previous research establishes direct relationships between support and engagement [74,111,112].

Social support was also not shown to be a direct predictor of dropout intention. As in the previous case, the observed mediations show that social variables influence belonging, and through this, engagement. This last variable once again plays a key role since the set of social variables only affects dropout intention by affecting the motivation of students. This finding also contributes to a deeper understanding considering that preliminary research focused on the direct relationship of social support and the dropout intention.

In the same way, the perceived social integration could have been modified taking into account the COVID-19 pandemic. This perceived social integration, as well as the sense of belonging to the institution, may have been diminished to the detriment of face-to-face classes, a fact that will need to be taken into consideration for future research. In addition, social isolation and the sense of loneliness have also been variables that have suffered for variations due to this situation, as has been observed in studies such as that of Zurlo et al. [113].

\subsection{Applications of the results}

On the one hand, the results contribute, in a certain way, to a better understanding of the relationships between the variables that have been analyzed throughout the investigation, deepening and distinguishing the relative influence of the variables. In this way, as has been discussed, new lines of research emerge and contribute to furthering the understanding of the phenomenon.

On the other hand, they contribute to the identification of relevant variables for the dropout intention and their relationships. As indicated, the variables included are susceptible to early detection (except for previous performance). This knowledge can contribute to the development of preventive actions that contribute to the social and academic integration of the student body, to maintain and increase their engagement and to reduce university dropout intention and therefore the consummate abandonment.

In order to prevent or alleviate the phenomenon of university dropout, some recommendations can be outlined, such as the implementation of actions that promote adaptation in the university environment with programs such as reception days [114] or programs to help the retention through the implementation of tutoring programs, first-year seminars or the improvement of the use of technology to make teaching more flexible and motivating for students, among others [115]. These and other measures could improve social and academic adaptation of the student, which in turn will lead to greater support mechanisms for not dropping out during the first year (one of the academic years in which the risk of dropping out increases). In addition, the improvement of the use of new technologies since the beginning of higher education, will allow accessibility and better understanding of the use of Information and Communication Technologies to all those who are studying in online or hybrid mode as a consequence of the COVID-19 pandemic.

\subsection{Limitations}

This research has some limitations. On the one hand this sample, although it represents a significant amount of the population, is limited to a single educational institution, which limits the possibilities of extrapolating the results to different contexts. For this reason, the results contribute to suggest the indicated relationships and the proposed explanations so that they are deepened in later research. However, in future research we will consider to deepen the analysis, incorporating a complete mediation model to analyze the mediations produced between the academic and social variables of the model, engagement and the intention to drop out.

On the other hand, this model does not consider other variables that could be important, such as self-efficacy perceived by the students. This variable could properly ex- 
plain the relationship between performance and engagement. According to De Besa et al. [116], the more perceived self-efficacy increases, that is, the more aware the individual is that they have their own abilities to carry out any action, the more their expectations of results increase. Therefore, future research should take these limitations into account to be able to propose a more adjusted model according to the results obtained in the present research. We also consider it relevant to retest the model in normal contexts, without covid-19.

Considering that the instruments used are self-report, this can generate simulation biases, social desirability in the responses or scalar errors. In addition, there are limitations inherent to the research design, since as it is transversal, a sample is taken from a specific moment, not allowing causal relationships to be established.

Author Contributions: Conceptualization, J.M.A., V.I.V., C.G.G., G.F.O. and J.B.R.; methodology, J.M.A., V.I.V., C.G.G., G.F.O. and J.B.R.; software, J.M.A., V.I.V., C.G.G., G.F.O. and J.B.R.; validation, J.M.A.; formal analysis, J.M.A., V.I.V., C.G.G., G.F.O. and J.B.R.; investigation, J.M.A., V.I.V., C.G.G., G.F.O. and J.B.R.; resources, J.M.A., V.I.V., C.G.G., G.F.O. and J.B.R.; data curation, J.M.A.; writing-original draft preparation, J.M.A., V.I.V., C.G.G., G.F.O. and J.B.R.; writing-review and editing, J.M.A., V.I.V., C.G.G., G.F.O. and J.B.R.; visualization, J.M.A., V.I.V., C.G.G., G.F.O. and J.B.R.; supervision, J.M.A.; project administration, J.M.A.; funding acquisition, J.M.A. All authors have read and agreed to the published version of the manuscript.

Funding: This research was funded by the Agencia Nacional de Investigación y Desarrollo (ANID) through the scholarship for doctoral studies, grant number 21180225.

Conflicts of Interest: The authors declare no conflict of interest.

\section{References}

1. Ferreyra, M.M.; Avitabile, C.; Botero, J.; Haimovich, F.; Urzúa, S. Momento decisivo: La educación superior en América Latina y el Caribe. Grupo lo Mundial 2017. http://doi.org/10.1596/978- 1-4648-1014-5

2. Ortiz-Lozano, J.M.; Rua-Vieites, A.; Bilbao-Calabuig, P.; Casadesús-Fa, M. University student retention: Best time and data to identify undergraduate students at risk of dropout. Innovations in Education and Teaching International 2018, 57, 74-85. http://doi.org/10.1080/14703297.2018.1502090

3. Servicio de Información en Educación Superior. Informe 2020 retención de 1er año de pregrado cohortes 2015-2019, 2020. Chile: Ministerio de Educación.

4. Lattuada, M.J. Deserción y retención en las unidades académicas de educación superior: una aproximación a las causas, instrumentos y estrategias que contribuyen a conocer y morigerar su impacto. Debate Universitario 2017, 10, 100-113.

5. Tuero, E.; Ayala, I.; Urbano, A.; Herrero, F.J.; Bernardo, A.B. Intención de abandonar la carrera: Influencia de variables personales y familiares. Revista Fuentes 2020, 22, 142-152. http://doi.org/10.12795/revistafuentes.2020.v22.i2.05

6. Morentin-Encina, J.; Ballestero, B.; Mateus, S. ¿Igualdad de oportunidades? Más que el mero acceso: narrativas de jóvenes con trayectorias de fracaso y abandono temprano de la educación en España y Portugal. Revista Fuentes 2019, 21, 143-149. http://doi.org/10.12795/revistafuentes.2019.v21.i2.01

7. Bethencourt, J.T.; Cabrera, L.; Hernández-Cabrera, J.A.; Álvarez-Pérez, P.; González-Alfonso, M. Variables psicológicas y educativas en el abandono universitario. Revista Electrónica de Investigación Psicoeducativa 2008, 6, 603-622

8. González-Ramírez, T.; Pedraza-Navarro, I. Variables sociofamiliares asociadas al abandono de los estudios universitarios. Educatio siglo XXI 2017, 35, 365-388. http://doi.org/10.6018/j/298651

9. Bernardo, A.B.; Cervero, A.; Esteban, M.; Tuero, E.; Casanova, J.R.; Almeida, L.S. Freshmen Program Withdrawal: Types and Recommendations. Front. Psychol. 2017, 8, 1- 11. http://doi.org/10.3389/fpsyg.2017.01544

10. Cervero, A.; Bernardo, A.B.; Esteban, M.; Tuero, E.; Carbajal, R.; Núñez, J.C. Influencia en el abandono universitario de variables relacionales y sociales. Revista de estudios e investigación en Psicología y Educación 2017, Extr., 46-49. http://doi.org/10.17979/reipe.2017.0.12.2531

11. Matteo, R.; Angeli dos Santos, A.; Portela, S. Motivos para evasão, vivências acadêmicas e adaptabilidade de carreira em universitários. Psico 2016, 47, 288-297. http://doi.org/10.15448/1980- 8623.2016.4.23872

12. Castro-López, A.; Cervero, A.; Galve-González, C.; Puente, J.; Bernardo, A.B. Evaluating critical success factors in the permanence in Higher Education using multi-criteria decision making. Higher Education Research and Development 2021. http://doi.org/10.1080/07294360.2021.1877631

13. Maluenda, J.; Varas, M.; Díaz-Mujica, A.; Bernardo, A.B. Propiedades Psicométricas del University Student Engagement Inventory en Estudiantes de Ingeniería Chilenos. Revista Iberoamericana de Diagnóstico y Evaluación - e Avaliação Psicológica 2020, 4 , 77-90. http://doi.org/10.21865/RIDEP57.4.06 
14. Bernardo, A.B.; Cervero, A.; Esteban, M.; Fernández-González., A.; Solano, P.; Agulló, E. Variables relacionadas con la intención de abandono universitario en el periodo de transición. Revista d'Innovació Docent Universitària 2018, 10, 122-130. http://doi.org/10.1344/RIDU2018.10.11

15. Bernardo, A.B.; Esteban, M.; Fernández, E.; Cervero, A.; Tuero, E.; Solano, P. Comparison of Personal, Social and Academic Variables Related to University Drop-out and Persistence. Front. Psychol. 2016, 7, 1-9. http://doi.org/10.3389/fpsyg.2016.01610

16. Coman, C.; Tiru, L.G.; Mesesan-Schmitz, L.; Stanciu, C.; Bularca, M.C. Online Teaching and Learning in Higher Education during the Coronavirus Pandemic: Students' Perspective. Sustainability 2020, 12. http://doi.org/10.3390/su122410367

17. Potra, S.; Pugna, A.; Pop, M.D.; Negrea, R.; Dungan, L. Facing COVID-19 Challenges: 1st-Year Students' Experience with the Romanian Hybrid Higher Educational System. International Journal of Environmental Research and Public Health 2021, 18, http://doi.org/10.3390/ijerph 18063058

18. Rosario-Rodríguez, A.; González-Rivera, J.A.; Cruz-Santos, A.; Rodríguez-Ríos, L. Demandas tecnológicas, académicas y psicológicas en estudiantes universitarios durante la pandemia por COVID-19. Revista Caribeña de Psicología 2020, 4(2), 176-185. http://doi.org/10.37226/rcp.v4i2.4915

19. Maluenda-Albornoz, J.; Bernardo, A.B.; Galve-González, C.; Flores-Oyarzo, G.; InfanteVillagrán, V.; Díaz-Mujica, A. Variables predictoras de la expectativa de desempeño y la intención de abandono en contexto de educación virtual de emergencia en estudiantes universitarios chilenos. Revista Caribeña de Investigación Educativa 2021, 5, 81-91. http://doi.org/10.32541/recie.2021.v5i2.pp81- 91

20. Zaccoletti, S.; Camacho, A.; Correia, N.; Aguiar, C.; Mason, L.; Alves, R.A.; Daniel, J.R. Parents' Perceptions of Student Academic Motivation During the COVID-19 Lockdown: A Cross-Country Comparison. Front. Psychol. $2020,11$. http://doi.org/10.3389/fpsyg.2020.59267

21. Mooney, C.; Becker, B.A. Investigating the Impact of the COVID-19 Pandemic on Computing Students' Sense of Belonging. In Proceedings of the 52nd ACM Technical Symposium on Computer Science Education (SIGCSE '21), Virtual Event, United States, March 13rd-20th, 2021. http://doi.org/10.1145/3408877.3432407

22. Markel, J.M.; Guo, P.J. Designing the Future of Experiential Learning Environments for a Post-COVID World: A Preliminary Case Study. Symposium on the New Future of Work, August 3rd-5 $5^{\text {th }}, 2020$.

23. Stebleton, M.J.; Soria, K.M.; Huesman, R.L.; Torres, V. Recent Immigrant Students at Research Universities: The Relationship Between Campus Climate and Sense of Belonging. Journal of College Student Development 2014, 55, 196-202. http://doi.org/10.1353/csd.2014.0019

24. Mooney, C.; Becker, B.A. Sense of Belonging: The Intersectionality of SelfIdentified Minority Status and Gender in Undergraduate Computer Science Students. United Kingdom and Ireland Computing Education Research conference 2020, $20,24-30$. http://doi.org/10.1145/3416465.3416476

25. Deborah, T. Sudden change of pedagogy in education driven by COVID-19: Perspectives and evaluation from a developing country. Research in Globalization 2020, 2. http://doi.org/10.1016/j.resglo.2020.100029

26. Rodríguez-Marín, J.; Pastor, M.Á.; López-Roig, S. Afrontamiento, apoyo social, calidad de vida y enfermedad. Psicothema 1993, 5, 349-372.

27. Bernardo, A.B.; Tuero, E.; Cervero, A.; Dobarro, A.; Galve-González, C. Acoso y ciberacoso: Variables de influencia en el abandono universitario. Comunicar 2020, 28, 63-72. http://doi.org/10.3916/C64-2020-06

28. Orcasita, L.T.; Uribe, A.F. La importancia del apoyo social en el Bienestar del adolescente. Psychologia Avances de la Disciplina 2010, 4, 69-82.

29. Fernández-Lasarte, O.; Goñi, E.; Camino, I.; Ramos-Díaz, E. Apoyo social percibido e implicación escolar del alumnado de educación secundaria.Perceived social support and school engagement in secondary students. Revista Española de Pedagogía 2019, 77, 123-141. http://doi.org/10.22550/REP77-1-2019-06

30. Ensel, W.M.; Lin, N. The life stress paradigm and psychological distress. Journal of Health and Social Behavior 1991, 32, $321-341$. http://doi.org/10.2307/2137101

31. Davidson, C.; Wilson, K. Reassessing Tinto's conceptos o social and academic integration in student retention. Journal of College Student Retention 2014, 15, 329-346. http://doi.org/10.2190/CS.15.3.b

32. Instituto Internacional para la Educación Superior en América Latina y el Caribe. COVID-19 y educación superior: De los efectos inmediatos al día después. Análisis de impactos, respuestas políticas y recomendaciones. UNESCO, 2020.

33. Cacioppo, J.; Hawkley, L. Perceived social isolation and cognition. Trends in Cognitive Sciences 2009, 13, 447-454. http://doi.org/10.1016/j.tics.2009.06.005

34. Perlman, D.; Peplau, L.A. Toward a Social Psychology of Loneliness. In Personal Relationships: Relationships in Disorder, $1^{\text {st }}$ ed.; Academic Press: United States, 1981, pp. 31-56.

35. Ali, A.; Smith, D. Comparing Social Isolation Effects on Students Attrition in Online Versus Face-to-Face Courses in Computer Literacy. Issues in Informing Science and Information Technology 2015, 12, 11-20.

36. Peltzer, K.; Pengpid, S. Loneliness: Its correlates and associations with health risk behaviours among university students in 25 countries. Journal of Psychology in Africa 2017, 27, 247-255. http://doi.org/10.1080/14330237.2017.1321851

37. López-Angulo, Y.; Pérez-Villalobos, M.V.; Cobo-Redón, R.C.; Díaz-Mujica, A. Apoyo social, sexo y área del conocimiento en el rendimiento académico autopercibido de estudiantes universitarios chilenos. Formación universitaria 2020, 12, 11-18. http://doi.org/10.4067/S0718-50062020000300011

38. Glaría, R.; Carmona, L.; Martín, S.; Pérez, C.; Ponce, P. Burnout y engagement académico en fonoaudiología. Investigación En Educación Médica 2016, 5, 17-23. http://doi.org/10.1016/j.riem.2015.08.006 
39. Marín, D.; Snahueza, O. Apoyo social: uso del concepto en enfermería. Horizontes Enfermería 2016, 27, 32-40. http://doi.org/10.7764/Horiz_Enferm.27.2.32

40. Anistranski, J.A.; Brown, B.B. A Little Help From Their Friends? How Social Factors Relate to Students' Sense of Belonging at a Large Public University. Journal of College Student Retention: Research, Theory and Practice 2021. http://doi.org/10.1177/1521025120985107

41. Brooms, D.R. Helping us think about ourselves: Black males' sense of belonging through connections and relationships with faculty in college. International Journal of Qualitative Studies in Education 2020, 33(9), 921-938.http://doi.org/10.1080/09518398.2019.1687956

42. Choi, S.; Weng, S.; Park, H.; Lewis, J.; Harwood, S.A.; Mendenhall, R.; Huntt, M.B. Sense of Belonging, Racial Microaggressions, and Depressive Symptoms among Students of Asian Descent in the United States. Smith College Studies in Social Work 2021. http://doi.org/10.1080/00377317.2021.1882922

43. Dueñas, M.; Gloria, A.M. ¡Pertenecemos y tenemos importancia aquí! Exploring Sense of Belonging and Mattering for First-Generation and Continuing-Generation Latinx Undergraduates. Hispanic Journal of Behavioral Sciences 2020, $42,95-116$. http://doi.org/10.1177/0739986319899734.

44. Whitten, D.; James, A.; Roberts, C. Factors That Contribute to a Sense of Belonging in Business Students on a Small 4-Year Public Commuter Campus in the Midwest. Journal of College Student Retention: Research, Theory and Practice 2020, $22,99-117$. http://doi.org/10.1177/1521025117726520

45. Garza, T.; Huerta, M.; García, H.A.; Lau, J. Exploring Sense of Belonging, Socioacademic Integrative Moments, and Learning Communities Related to ELs' Persistence Based on Reenrollment Decisions in Community Colleges. Community College Review 2021, 49, 30-51. http://doi.org/10.1177/0091552120964873

46. Itzhaki, Y. The Different Role of Mentor Support Along the High-School Dropout Process. Youth E Society 2018, 1-28. http://doi.org/10.1177/0044118X18803260

47. Gilardi, S.; Guglielmetti, C. University Life of Non-Traditional Students: Engagement Styles and Impact on Attrition. The Journal of Higher Education 2011, 82, 33-53. http://doi.org/10.1353/jhe.2011.0005

48. Pérez, M.; Cobo, R.; Matos, L.; Hernández, H.; Del Valle, M.; Díaz-Mujica, A. Variables cognitivo-motivacionales como predictoras del ajuste a la vida universitaria y la intención de abandonar los estudios en estudiantes de primer año. VII Conferencia Latinoamericana sobre el Abandono en la Enseñanza Superior (CLABES), Argentina, november 15th-17th 2017.

49. Syed, N.K.; Syed, M.H.; Meraya, A.M.; Albarraq, A.A.; Al-kasim, M.A.; Alqahtani, S.; Antar, H.; Yasmeen, A.; Banji, O.J.F.; Hassan, M. The association of dietary behaviors and practices with overweight and obesity parameters among Saudi university students. PLOS ONE 2020, 15. http://doi.org/10.1371/journal.pone.0238458

50. Fernández, M.; Álvarez, J.; Ávalos, I.; Cuevas, M.; Barros, C.; Díaz, F.; González-Castellón, E.; González-González, D.; Hernández-Fernández, A.; Ibañez, P.; Lizarte, E. Evaluation of the Emotional and Cognitive Regulation of young people in a lockdown situation due to the Covid-19 pandemic. Front. Psychol. 2020, 11. http://doi.org/10.3389/fpsyg.2020.565503

51. Abdalellah, O.M.; Basin, A.K.; Abdul, N.; Vigil, J.V. Emergency remote teaching during Coronavirus pandemic: The current trend and future directive at Middle East College Oman. Innovative Infrastructure Solutions 2020, 5, 4-11. http://doi.org/10.1007/s41062-020-00326-7

52. Barrera, J.; Tovar-Torres, C.; Daza, J.; Polanco, J. Perception of virtual university education in the covid19. Revista Iberica de Sistemas e Tecnologias de Informacao 2020, 31, 297-308.

53. Galvin, J.; Evans, M.S.; Nelson, K.; Richards, G.; Mavritsaki, E.; Giovazolias, T.; Koutra, K.; Mellor, B.; Zurlo, M.C.; Smith, A.P.; Vallone, F. Technostress, Coping, and Anxious and Depressive Symptomatology in University Students During the COVID-19 Pandemic. Europe's Journal of Psychology 2021. http://doi.org/10.23668/psycharchives.5108

54. Marques, B.; Marques, R.; Reis, R. Student's social vulnerability in distance learning in covid-19 times. Proceedings of the 14th IADIS International Conference e-Learning, july $12^{\text {th }} 2020$.

55. Tahir, M.; Gökalp, E.; Nurcan, E. ICT-Based Distance Higher Education: A Necessity During the Era of COVID-19 Outbreak. In Emerging Technologies During the Era of COVID-19 Pandemic, 1 ${ }^{\text {st }}$ ed; Arpaci, I., Al-Emran, M., Al-Sharafi, M.A., Marques, G, Eds.; Springer International Publishing: United States, 2021; pp. 365-385.

56. Al Rawashdeh, A.Z.; Mohammed, E.Y.; Al Arab, A.R.; Alara, M.; Al-Rawashdeh, A.B. Advantages and Disadvantages of Using e-Learning in University Education: Analyzing Students' Perspectives. The Electronic Journal of e-Learning 2021, 19, 107-117. http://doi.org/10.34190/ejel.19.3.2168

57. Ishmuhametov, I.; Kuzmenko, L. The Study of Students' Opinion on Learning Online in the Self-Isolation Period. Reliability and Statistics in Transportation and Communication 2021, 195, 857-867.

58. González-Tovar, M.; Hernández-Rodríguez, S. COVID-19 and Emotional Variables in a Sample of Chileans. Front. Psychol. 2021, 12. http://doi.org/10.3389/fpsyg.2021.615268

59. Scotta, A.V.; Cortez, M.V.; Miranda, A.R. Insomnia is associated with worry, cognitive avoidance and low academic engagement in Argentinian university students during the COVID-19 social isolation. Psychology, Health $\mathcal{E}$ Medicine 2020. http://doi.org/10.1080/13548506.2020.1869796

60. Tinajero, C.; Martínez-López, Z.; Rodríguez, M.S.; Páramo, M.F. Perceived Social Support as a predictor of academic success in Spanish university students. Anales de Psicología 2020, 36, 134-142. http://doi.org/10.6018/analesps.344141

61. Mercado, A.; Hernández, A.V. El proceso de construcción de la identidad colectiva. Convergencia 2010, 53, $229-251$. 
62. Cole, D.; Newman, C.B.; Hypolite, L.I. Sense of Belonging and Mattering Among Two Cohorts of First-Year Students Participating in a Comprehensive College Transition Program. American Behavioral Scientist 2020, 64, $276-297$. http://doi.org/10.1177/0002764219869417

63. Drezner, N.D.; Pizmony-Levy, O. I Belong, Therefore, I Give? The Impact of Sense of Belonging on Graduate Student Alumni Engagement. Nonprofit and Voluntary Sector Quarterly 2020, 1-25. http://doi.org/10.1177/0899764020977687

64. Gillen-O'Neel, C. Sense of Belonging and Student Engagement: A Daily Study of First- and Continuing-Generation College Students. Research in Higher Education 2021, 62, 45-71. http://doi.org/10.1007/s11162-019-09570-y

65. Holloway-Friesen, H. The Role of Mentoring on Hispanic Graduate Students' Sense of Belonging and Academic Self-Efficacy. Journal of Hispanic Higher Education 2021, 20, 46-58. http://doi.org/10.1177/1538192718823716

66. Won, S.; Hensley, L.C.; Wolters, C.A. Brief Research Report: Sense of Belonging and Academic Help-Seeking as Self-Regulated Learning. The journal of experimental education 2021, 89, 112-124. http://doi.org/10.1080/00220973.2019.1703095

67. Tinto, V. Through the eyes of students. Journal of College Student Retention: Research, Theory and Practice 2017, 19, 254-269. http://doi.org/10.1177/1521025115621917

68. Baumeister, R.F.; Leary, M.R. The need to belong: Desire for interpersonal attachments as a fundamental human motivation. Psychological Bulletin 1995, 117, 497-529. http://doi.org/10.1037/0033-2909.117.3.497

69. Torres, J.B.; Solberg, V.S. Role of self-efficacy, stress, social integration, and family support in Latino college student persistence and health. Journal of vocational behavior 2021, 59, 53-63. http://doi.org/10.1006/jvbe.2000.1785

70. Capello, H. La identidad universitaria. La construcción del concepto. Revista Internacional de Ciencias Sociales y Humanidades 2015, 25, 33-53.

71. Boros, S.; Curseu, P.L. To be or not to be...identified. Explorations of students'(dis)identification in a Romanian university. Psihologia Resurselor Umane 2012, 10, 57-69.

72. Sedgwick M.; Rougeau J. Points of tension: a qualitative descriptive study of significant events that influence undergraduate nursing students' sense of belonging. Rural and Remote Health 2010, 10. http://doi.org/10.22605/RRH1569

73. Maluenda-Albornoz, J.; López-Angulo, Y.; Varas-Contreras, M.; Bernardo, A.B.; Díaz-Mujica, A.; Moraga, F.. Predictores psicosociales de la intención de abandono en estudiantes de ingeniería chilenos. Proceedings of the 9th Conferencia Latinoamericana sobre Abandono en Educación Superior CLABES, 2019.

74. Wilkins, S.; Butt, M.M.; Kratochvil, D.; Balakrishnan, M. Studies in Higher Education The effects of social identification and organizational identification on student commitment, achievement and satisfaction in higher education. Studies in Higher Education 2016, 41, 2232-2252. http://doi.org/10.1080/03075079.2015.1034258

75. Di Battista, S.; Pivetti, M.; Berti, C. Engagement in the university context: exploring the role of a sense of justice and social identification. Soc. Psychol. Educ. 2014, 17, 471-490. http://doi.org/10.1007/s11218-014-9255-9

76. Capone, V.; Caso, D.; Donizzetti, A.R.; Procentese, F. University Student Mental Well-Being during COVID-19 Outbreak: What Are the Relationships between Information Seeking, Perceived Risk and Personal Resources Related to the Academic Context? Sustainability 2020, 12. http://doi.org/10.3390/su12177039

77. Gopalan, M.; Brady, S.T. College Students' Sense of Belonging: A National Perspective. Educational Researcher 2019, 49, $134-137$. http://doi.org/10.3102/0013189X19897622

78. Bettencourt, G.M. “I Belong Because It Wasn't Made for Me": Understanding Working-Class Students' Sense of Belonging on Campus. The journal of higher education 2021, 92, 760-783. http://doi.org/10.1080/00221546.2021.1872288

79. LaCosse, J.; Murphy, M.C.; Garcia, J.A.; Zirkel, S. The role of STEM professors mindset beliefs on students anticipated psychological experiences and course interest. Journal of Educational Psychology 2020. http://doi.org/10.1037/edu0000620

80. Moore, M.Z. Fostering a Sense of Belonging Using a Multicontext Approach. Journal of College Student Retention: Research, Theory and Practice 2020, 0, 1-18. http://doi.org/10.1177/1521025120944828

81. Jiménez, M. Competencia social: intervención preventiva en la escuela. Infancia y Sociedad 2000, 24, 21 - 48.

82. Catalán, X.; Santelices, M.V. Rendimiento académico de estudiantes de distinto nivel socioeconómico en universidades: el caso de la Pontificia Universidad Católica de Chile. Calidad en la educación 2014, 40, 21-52. http://doi.org/10.4067/S0718-45652014000100002

83. Gallegos, J.A.; Campos, N.A.; Canales, K.A. Factores Determinantes en la Deserción Universitaria. Caso Facultad de Ciencias Económicas y Administrativas de la Universidad Católica de la Santísima Concepción (Chile). Formación Universitaria 2018, 11, 11-18.

84. Vergara-Díaz, G.; Peredo-López, H. Relación del desempeño académico de estudiantes de primer año de universidad en Chile y los instrumentos de selección para su ingreso. Revista Educación 2017, 41. http://doi.org/10.15517/revedu.v41i2.21514

85. Tinto, V. Completing college. Rethinking institutional action, $1^{\text {st }}$ ed.; The University Of Chicago Press: United Kingdom, 2012.

86. Bernardo, A.B.; Cerezo, R.; Rodríguez-Múñiz, L.J.; Núñez, J.C.; Tuero, E.; Esteban, M. Predicción del abandono universitario: Variables explicativas y medidas de prevención. Revista Fuentes 2015, 16, 63-84. http://doi.org/10.12795/revistafuentes.2015.i16.03

87. Esteban, M.; Bernardo, A.B.; Tuero, E.; Cerezo, R.; Núñez, J.C. El contexto sí importa: identificación de relaciones entre el abandono de titulación y las variables contextuales. European Journal of Education and Psychology 2016, 9, 79-88. http://doi.org/10.1016/j.ejeps.2015.06.001

88. Viale, H.E. Una aproximación teórica to the college student Drop Out. Revista Digital de Investigación en Docencia Universitaria 2014, 8, 59-74. http://doi.org/10.19083/ridu.8.366 
89. Maroco, J.; Maroco, A.L.; Alvares-Duarte, J.; Fredricks, J.A. University student's engagement: Development of the University Student Engagement Inventory (USEI). Psicologia Reflexão e Crítica 2016, 29, 1-12. http://doi.org/10.1186/s41155-016-0042-8

90. Fredricks, J.; Reschly, A.; Christenson, S. Handbook of student engagement interventions. Working with disengaged students, $1^{\text {st }}$ ed.; London Academic Press: United Kingdom, 2019.

91. Antúnez, Á.; Cervero, A.; Solano, P.; Bernardo, I.; Carbajal, R. Engagement: A New Perspective for Reducing Dropout through Self-Regulation. In Factors Affecting Academic Perfomance, $1^{\text {st }}$ ed,; González-Pienda, J.A., Bernardo, A.B., Núñez, J.C., Rodríguez, C.; Eds.; Nova Science Publishers: New York, United States, 2017; pp. 25-46.

92. Ryan, R.M.; Deci, E.L. Self-Determination Theory. Basic psychological needs in motivation, development, and wellness, $1^{\text {st }}$ ed.; Guilford press: United States, 2018.

93. Lerdpornkulrat, T.; Koul, R.; Poondej, C. Relationship between perceptions of classroom climate and institutional goal structures and student motivation, engagement and intention to persist in college. Journal of Further and Higher Education 2016, 42(1), 102-115. http://doi.org/10.1080/0309877X.2016.1206855

94. Truta, C.; Parv, L.; Topala, I. Academic Engagement and Intention to Drop Out: Levers for Sustainability in Higher Education. Sustainability 2018, 10. http://doi.org/10.3390/su10124637

95. Perets, E.; Chabeda, D.; Gong, A.; Huang, X.; Sang, T.; Yi, F.; Bathgate, M.; Yan E. Impact of the Emergency Transition to Remote Teaching on Student Engagement in a Non-STEM Undergraduate Chemistry Course in the Time of COVID-19. Journal of Chemical Education 2020, 97, 2439-2447. http://doi.org/10.1021/acs.jchemed.0c00879

96. Daniels, L.M.; Goegan, L.D.; Parker, P. The impact of COVID-19 triggered changes to instruction and assessment on university students' self-reported motivation, engagement and perceptions. Social Psychology of Education 2021, 24, $299-318$. http://doi.org/10.1007/s11218-021-09612-3

97. Pasion, R.; Paiva, T.O.; Fernandes, C.; Barbosa, F. The AGE effect on protective behaviors during the COVID-19 outbreak: sociodemographic. perceptions and psychological accounts. Front. Psychol. 2020, 11. http://doi.org/10.3389/fpsyg.2020.561785

98. Maroco, J.; Assunção, H.; Harju-Luukkainen, H.; Lin S.W.; Sit, P.S.; Cheung, K.C.; Maloa, B.; Ilic, I.S.; Smith, T.J.; Campos, J.A.D.B. Predictors of academic efficacy and dropout intention in university students: Can engagement suppress burnout? PLOS ONE 2020, 15. http://doi.org/10.1371/journal.pone.0239816

99. Yañez, R.; Perez, M.V.; Ahumada, L. Adaptación y validación de una escala de identificación organizacional con centros de estudio. Paideia 2006, 41, 65-76.

100. Maluenda-Albornoz, J.; Varas, M.; Bernardo, A.B.; Díaz-Mujica, A. Adaptación y evaluación psicométrica de la escala de identificación organizacional con centros educativos en estudiantes de ingeniería chilenos. Under review.

101. Díaz-Mujica, A. FONDECYT project $\mathrm{N}^{\circ} 1161502$, Modelo explicativo de la permanencia y el abandono de los estudios universitarios, basado en procesos cognitivo-motivacionales. Under review.

102. Russell, D. UCLA Loneliness Scale (Version 3): Reliability, validity and factor structure. Journal of Personality Assessment 1996, 66, 20-40. http://doi.org/10.1207/s15327752jpa6601_2

103. Kline, R.B. Principles and practice of structural equation modelling, $4^{\text {th }}$ ed.; Guilford Press: United States, 2011.

104. Muthén, L.K.; Muthén, B.O. MPLUS User's Guide, 7th ed.; Muthén \& Muthen: United States, 2012.

105. Hair, J.; Sarstedt, M.; Hopkins, L.; Kuppelwieser, V. Partial Least Squares Structural Equation Modeling (PLS-SEM): An Emerging Tool for Business Research. European Business Review 2014, 26, 106-121. http://doi.org/10.1108/EBR-10-2013-0128

106. Hair, J.; Black, W.; Babin, B.; Anderson, R. Multivariate Data Analysis, 7th ed.; Pearson: United Kingdom, 2014.

107. Ventura-León, J.; Caycho-Rodríguez, T. El coeficiente omega: un método alternativo para la estimación de la confiabilidad. Revista Latinoamericana de Ciencias Sociales, Niñez y Juventud 2017, 15, 625-627.

108. Álvarez-Pérez, P.R.; López-Aguilar, D. Estudios sobre deserción académica y medidas orientadoras de la prevención en la Universidad de La Laguna (España). Revista Paradigma 2017, 38, 48-71. http://doi.org/10.37618/PARADIGMA.1011-2251.2017.p48-71.id600

109. González-Gamarra, D.O.; Charry, J.M. Engagement en el estudio, inteligencia emocional y rendimiento académico en estudiantes de la escuela profesional de Ingeniería Forestal de la UNSAAC. Revista CEPROSIMAD 2018, 6, 6-17.

110. Straber, R. Learner's engagement in mathematics-theories, frameworks and results. Mathematical Educational Research Journal 2017, 29, 255-259. http://doi.org/10.1007/s13394-017-0208-4

111. Fernández-Lasarte, O.; Ramos-Díaz, E.; Goñi, E.; Rodríguez-Fernández, A. Estudio comparativo entre educación superior y educación secundaria: efecto del apoyo social percibido, el autoconcepto y la reparación emocional en el rendimiento académico. Educación XX1 2019, 22, 165-185. http://doi.org/10.5944/educXX1.22526

112. Rautanen, P.; Soini, T.; Pietarinen, J.; Psyhältö, K. Primary school students' perceived social support in relation to study engagement. European Journal of Psychology of Education 2020. http://doi.org/10.1007/s10212-020-00492-3

113. Zurlo, M.C.; Cattaneo, M.F.; Vallone, F. COVID-19 Student Stress Questionnaire: Development and Validation of a Questionnaire to Evaluate Students' Stressors Related to the Coronavirus Pandemic Lockdown. Front. Psychol. 2020. http://doi.org/10.3389/fpsyg.2020.576758

114. Fourie, C.M. Risk factors associated with first-year students' intention to drop out from a university in South Africa. Journal of Further and Higher Education 2018. http://doi.org/10.1080/0309877X.2018.1527023

115. Sandoval-Palis, I.; Naranjo, D.; Vidal, J.; Gilar-Corbi, R. Early Dropout Prediction Model: A Case Study of University Leveling Course Students. Sustainability 2020, 12. http://doi.org/10.3390/su12229314 
116. De Besa, M.R.; Gil, J.; García-González, A.J. Variables psicosociales y rendimiento académico asociados al optimismo en estudiantes universitarios españoles de nuevo ingreso. Acta Colombiana de Psicología 2019, 22, $152-163$. http://doi.org/10.14718/ACP.2019.22.1.8 